удк 343.21

DOI 10.17150/2500-4255.2018.12(2).266-274

\title{
СУАЕБНЫЙ ШТРАФ - НОВАЯ ИНАЯ МЕРА УГОЛОВНО-ПРАВОВОГО ХАРАКТЕРА
}

\author{
Л.А. Абашина, Г.Л. Минаков \\ Орловский государственный университет им. И.С. Тургенева, г. Орел, Российская Федерация
}

\section{Информация о статье \\ Дата поступления \\ 15 мая 2017 г. \\ Дата принятия в печать \\ 6 апреля 2018 г. \\ Дата онлайн-размещения 27 апреля 2018 г.}

\section{Ключевые слова}

Судебный штраф; возмещение ущерба; законный интерес; сроки уплаты штрафа; размер штрафа

\begin{abstract}
Аннотация. В соответствии с Федеральным законом "О внесении изменений в Уголовный кодекс Российской Федерации и Уголовно-процессуальный кодекс Российской Федерации по вопросам совершенствования оснований и порядка освобождения от уголовной ответственности» от 3 июля 2016 г. № 323-Ф3 Уголовный кодекс Российской Федерации был дополнен статьей 76.2 , подразумевающей новое основание для освобождения от уголовной ответственности - назначение судебного штрафа. Несмотря на то что правоприменительная практика освобождения виновного от уголовной ответственности в связи с назначением судебного штрафа на данный момент весьма немногочисленна по причине относительной новизны данного подинститута, уже возникают сложности в применении указанной нормы. В работе анализируются ст. 76.2, 104.4 и 104.5 УК РФ. Раскрывается суть судебного штрафа как иной меры уголовно-правового характера, отмечаются недостатки и неточности постановления Пленума Верховного Суда РФ «О применении судами законодательства, регламентирующего основания и порядок освобождения от уголовной ответственности» от 27 июня 2013 г. № 19 (в редакции постановления Пленума от 29 ноября 2016 г. № 56), образовавшиеся в связи с введением нового подинститута. Обращается внимание на условия освобождения от уголовной ответственности с назначением судебного штрафа, в том числе случаи невозможности его применения, требующие законодательного разрешения. Обосновывается вывод, что освобождение от уголовной ответственности с назначением судебного штрафа является не правом, а законным интересом виновного. Высказываются конкретные предложения по уточнению срока уплаты штрафа и его размеру, в том числе и применительно к несовершеннолетним.
\end{abstract}

\section{A COURT FINE AS A NEW CRIMINAL LAW MEASURE}

\author{
Liudmila A. Abaschina, Gennadiy L. Minakov \\ Orel State University named after I.S. Turgenev, Orel, the Russian Federation
}

Article info
Received
2017 May 15
Accepted
2018 April 6
Available online
2018 April 27
Keywords
Court fine; compensation for damages;
a legitimate interest; payment schedule
for fines; size of the fine

Abstract. According to the Federal Law «On Changes in the Criminal Code of the Russian Federation and the Criminal Procedure Code of the Russian Federation regarding the Improvement of the Basis and Procedure of Exemption from Criminal Liability» of July 3, 2016 № 323-\$3 the Criminal Code of the Russian Federation was supplemented by Art. 76.2, which provides a new ground for exemption from criminal liability - a court fine. Although the practice of exempting from criminal liability by imposing court fines is at present rather modest due to the relative novelty of such an institute, there appear to be certain difficulties in the enforcement of this legal norm. The paper analyzes Art. 76.2, 104.4 and 104.5 of the Criminal Code of the Russian Federation. The authors describe the essence of a court fine as an alternative criminal law measure and point out the flaws and inaccuracies in the Resolution of the Plenary Session of the Russian Federation Supreme Court «On the Use of Legislation Regulating the Basis and Order of Exemption from Criminal Liability by Courts» of June 27, 2013 No 19 (in the edition of the Resolution of the Plenary Session of November 29, 2016 No 56) that appeared in connection with the introduction of this new institute. The authors also draw attention to the conditions of exemption from criminal liability by imposing court fines, including the cases when it cannot be enforced, which require a legislative solution. They present arguments to support their conclusion that the imposition of a court fine is not a right, but a legitimate interest of the guilty person. The authors also offer some ideas on specifying the fine payment schedule and size, including its imposition of minors. 
Федеральным законом от 3 июля 2016 г. № 323-Ф3 ${ }^{1}$ УК РФ был дополнен статьей 76.2, предусматривающей новый вид освобождения от уголовной ответственности - с назначением судебного штрафа. Этим же законом в разд. VI «Иные меры уголовно-правового характера» введена новая глава - гл. 15.2 «Судебный штраф». Она включает две статьи: ст. 104.4 «Судебный штраф» и ст. 104.5 «Порядок определения размера судебного штрафа».

Введение нового вида освобождения от уголовной ответственности, с одной стороны, представляет собой проявление принципов справедливости и гуманизма, а с другой - стимулирует лиц, совершивших преступления, к активному положительному постпреступному поведению. Причем этот вид освобождения от уголовной ответственности не позволяет виновному остаться без уголовно-правовых последствий совершенного преступления.

Из содержания ст. 76.2 УК РФ следует возможность освобождения судом от уголовной ответственности лица, впервые совершившего преступление небольшой или средней тяжести, с назначением ему судебного штрафа, однако реализоваться эта возможность может только при определенных условиях, которые можно объединить в три группы. Для практической реализации этого законодательного положения важна, во-первых, категория преступления: оно должно быть небольшой или средней тяжести; во-вторых, лицо должно совершить преступление в первый раз; в-третьих, лицо должно проявить себя с положительной стороны в рамках позитивного криминального поведения, т.е. возместить ущерб или загладить причиненный вред иным образом. Что подразумевается под другими способами заглаживания причиненного вреда, законодатель в данной норме не раскрывает, что показывает важность для правореализационной деятельности руководящих указаний и разъяснений Верховного Суда РФ, ликвидирующих нормативные лакуны посредством данного им толкования. Высшая судебная инстанция нашей страны обозначила свою правовую позицию в постановлении Пленума Верховного Суда РФ «О применении судами

${ }^{1}$ О внесении изменений в Уголовный кодекс Российской Федерации и Уголовно-процессуальный кодекс Российской Федерации по вопросам совершенствования оснований и порядка освобождения от уголовной ответственности : федер. закон от 3 июля 2016 г. № 323Ф3 // Российская газета. 2016. 8 июля. законодательства, регламентирующего основания и порядок освобождения от уголовной ответственности» от 27 июня 2013 г. № $19^{2}$ (в редакции постановления Пленума от 29 ноября 2016 г. № 56) (далее - постановление Пленума).

В п. 2 указанного постановления Пленума раскрывается, кого именно стоит причислять к лицам, впервые совершившим преступление. Согласно разъяснениям, данным высшей судебной инстанцией, к ним относятся следующие категории субъектов:

- лица, ранее не осуждавшиеся за совершение одного или нескольких преступлений (причем квалификация преступных деяний в данном случае значения не имеет), хотя и совершившие их;

- лица, ранее совершившие преступление, приговор по которому не имеет законной силы из-за невступления в действие на момент совершения такими субъектами нового преступления;

- лица, признанные судом преступниками, однако в силу обстоятельств правовые последствия привлечения этих лиц к уголовной ответственности были устранены;

- лица, признанные преступниками и осужденные в качестве таковых, но в отношении такого деяния, которое на сегодняшний момент не является преступным;

- лица, ранее освобожденные от уголовной ответственности.

Кроме перечисленных случаев, изложенных в правовой позиции высшей судебной инстанции, при определении преступления как совершенного впервые нельзя обойти вниманием и нормы уголовного законодательства: так, по ч. 2 ст. 86 УК РФ лицо считается несудимым, если оно было освобождено от наказания. Имеются в виду положения ст. 80.1 УК РФ, ч. 1 ст. 81 УК РФ, ст. 83 УК РФ, ст. 92 УК РФ, в которых обозначено, что субъект может быть освобожден от наказания при изменении обстановки или в случае болезни (в данном случае, как и при истечении давностного срока обвинительного судебного акта, возможно и освобождение от отбывания наказания); отдельным основанием для специфической категории субъектов (малолетних) освобождения от наказания выступает возможность применения к ним принудительных мер

${ }^{2}$ О применении судами законодательства, регламентирующего основания и порядок освобождения от уголовной ответственности : постановление Пленума Верхов. Суда РФ от 27 июня 2013 г. № 19 // Бюллетень Верховного Суда РФ. 2006. № 8. 
воспитательного воздействия или с помещением в специальное учебно-воспитательное учреждение закрытого типа [1, с. 56].

Разъяснения по преступлениям небольшой и средней тяжести даны в ч. 2, 3 ст. 15 УК РФ. Вместе с тем не исключена ситуация, когда суд при вынесении итогового акта по уголовному делу, применив ч. 6 ст. 15 УК РФ, произведет изменение категории совершенного преступного деяния на менее тяжкую, например средней тяжести. Возникает вопрос: можно ли в таком случае применить ст. 76.2 УК РФ? В п. 26 постановления Пленума отмечалось, что в подобных случаях, если имеются основания, обозначенные в ст. 75, 76, 76.1 и 78 УК РФ, лицо не будет отбывать назначенное наказание в связи с освобождением от этого. Но 29 ноября 2016 г. данный пункт был исключен. Как представляется, в этой связи применение ст. 76.2 УК РФ невозможно. В п. 26 Верховный Суд вышел за пределы своей компетенции. Он фактически взял на себя правотворческие функции, описав новый, не закрепленный в законодательстве вид освобождения от наказания, т.е. освобождение от наказания при наличии оснований, указанных в ст. 75, 76, 76.1 и 78 УК РФ. Однако, применив телеологическое толкование, высшая судебная инстанция, перечислив эти четыре нормы и рекомендуя нижестоящим судам опираться на них при определении возможности освобождения от наказания, допустила следующую ошибку - смешение оснований освобождения от уголовной ответственности и освобождения от наказания (а в этих статьях обозначен именно первый случай, и применение его ко второму случаю как раз и является ошибочным). При постановлении судом итогового процессуального акта, носящего обвинительный характер, освобождение от наказания осужденного лица возможно, но только по основаниям, отмеченным в гл. 12 «Освобождение от наказания». Поэтому вполне обоснованно, что п. 26 постановления Пленума был исключен.

Ущерб, о котором идет речь в ст. 76.2 УК РФ, представляет собой причиненный имущественный вред, который может быть возмещен в натуральном или денежном выражении (например, компенсация стоимости или ремонт утраченного или поврежденного имущества и т.д.) $[2$, с. 17].

Законодатель счел возможным изменить устойчивое выражение «заглаживание вины» на «заглаживание вреда» в качестве легальной дефиниции, не проявив, однако, ее семантиче- ски. В этой связи данное терминологическое сочетание также дается в трактовке высшей судебной инстанции. С точки зрения Верховного Суда РФ, оно фактически включает в себя компенсацию морального вреда, но с определенным изменением специфики этой дефиниции: ранее в своем постановлении 1994 г. ${ }^{3}$ Верховный Суд признавал моральный вред вредом неимущественным, хотя и компенсируемым в денежной или иной материальной форме (п. 10), сейчас суд еще более конкретизирует это понятие, отмечая возможность не только денежной, но и имущественной его компенсации, включив ее в качестве отдельной составляющей в «заглаживание вреда». Помимо компенсации морального вреда к «заглаживанию» суд также относит принесение извинений (без упоминания, однако, что они имеют значение только при их принятии со стороны потерпевшей стороны), а также ограничивается указанием на «иные меры», призванные восстановить права потерпевшего и законные интересы личности, общества и государства (п. 2.1 постановления Пленума), не наполняя их конкретными примерами. Неясно в данном случае, почему Верховный Суд РФ решил разграничить права и интересы, не совместив их воедино: в постановлении отдельно сказано про «права потерпевшего» и затем про «интересы личности». Интересным представляется, что высшая судебная инстанция допускает, что «заглаживанием вреда» будет заниматься (или может заниматься) и не сам субъект преступления, а иные лица при условии полученного на то согласия субъекта, совершившего преступное деяние, и (или) выполняя его просьбу. Важным обстоятельством, которое подчеркивает высшая судебная инстанция (п. 3), является необходимость заглаживания вреда в качестве уже состоявшегося факта, а не как обещание/ обязательство сделать это в будущем. Последнее не имеет значения для освобождения этого лица от уголовной ответственности с назначением судебного штрафа.

Полагаем возможным применение данного института и в случае, когда виновное лицо не имеет объективной возможности в силу отсутствия ущерба или вреда выполнить это условие. В литературе на этот счет высказано противоположное суждение, с которым трудно согласить-

\footnotetext{
${ }^{3}$ Некоторые вопросы применения законодательства о компенсации морального вреда : постановление Пленума Верхов. Суда РФ от 20 дек. 1994 г. № 10 : (в ред. от 6 февр. 2007 г.) // Российская газета. 1995. 8 февр.
} 
ся [3, с. 126]. Невозможность в указанной ситуации освобождения от уголовной ответственности с назначением штрафа поставит в неравное положение лиц, совершивших преступления, не повлекшие ущерба или вреда, и лиц, совершивших преступления с причинением ущерба или вреда. Последние в силу этого будут иметь возможность проявить свое позитивное постпреступное поведение. Например, если лицо совершит покушение на кражу без отягчающих обстоятельств (попытается вынести из магазина бутылку коньяка стоимостью 3 тыс. р.), то применять ст. 76.2 УК РФ к нему нельзя. Если же будет совершена квалифицированная кража группой лиц по предварительному сговору с незаконным проникновением в помещение либо иное хранилище на сумму в 240 тыс. р. (преступление, характеризующееся большей общественной опасностью), то применять ст. 76.2 УК РФ можно [4; 5].

Следует заметить, что органом, применяющим анализируемый вид освобождения от уголовной ответственности, является только суд. Причем, поскольку в ст. 76.2 УК РФ использован термин «может быть», реализация данной возможности лицом, совершившим преступление, зависит от усмотрения суда. Поэтому освобождение от уголовной ответственности с назначением судебного штрафа представляет собой не право, а законный интерес виновного [6; 7]. Даже при выполнении им всех условий, обозначенных в ст. 76.2 УК РФ, суд может отказать виновному в освобождении от уголовной ответственности. У суда должна быть уверенность, что лицо, освобожденное от уголовной ответственности, оправдает его доверие и станет законопослушным членом общества, т.е. исправится без назначения наказания.

Например, Сарапульским районным судом гражданину А., впервые совершившему преступление средней тяжести и загладившему причиненный преступлением вред, было отказано в применении ст. 76.2 УК РФ ввиду того, что он совершил преступление в состоянии опьянения. Суд признал данное обстоятельство отягчающим ${ }^{4}$.

Позиция законодателя о закреплении правовой возможности освобождения от уголовной ответственности с назначением судебного

4 Приговор Сарапульского районного суда (Удмуртская Республика) от 6 сентября 2016 г. по делу № 1-72/2016 ; Сводные статистические сведения о состоянии судимости в России за 2016 год // Судебный департамент при Верховном Суде Российской Федерации. URL: http://www.cdep.ru/index.php?id=79 HYPERLINK. штрафа на уровне законного интереса, а не на уровне субъективного права представляется вполне обоснованной. При принятии решения оправданным является всесторонний анализ преступного деяния с точки зрения фактических обстоятельств его совершения, характера и степени его общественной опасности, а также анализ личности обвиняемого, в том числе количества совершенных им преступлений, наличие снятых судимостей, а также смягчающих и отягчающих обстоятельств, данных, характеризующих личность виновного [8; 9].

На уровне законного интереса закреплен и такой имеющий длительную историю пребывания в УК РФ вид освобождения от уголовной ответственности, как освобождение от уголовной ответственности в связи с деятельным раскаянием (ст. 75 УК РФ).

Подчеркнем также определенную взаимосвязь новеллы УК РФ, представленной ст. 76.2 УК РФ, и ст. 75 УК РФ, предусматривающей возможность освобождения от уголовной ответственности в связи с деятельным раскаянием. Отметим в этой связи, что спектр условий, которые должен выполнить субъект преступления, претендующий на освобождение от уголовной ответственности в связи с деятельным раскаянием, гораздо шире, чем с назначением судебного штрафа. В последнем случае законодатель не ставит в качестве необходимых выполнение таких условий, которые можно отнести к позитивному посткриминальному поведению. Например, субъект добровольно явился с повинной или деятельно способствовал раскрытию и расследованию совершенного преступления. Помимо этого, не требуется утрата лицом, совершившим преступление, общественной опасности. Как видим, условия освобождения при деятельном раскаянии являются более многочисленными и серьезными. Поэтому видится, что, не сумев выполнить все условия, предусмотренные ст. 75 УК РФ, либо получив отрицательный ответ суда на просьбу об освобождении от уголовной ответственности в связи с деятельным раскаянием, обвиняемый может претендовать на реализацию в отношении него положений ст. 76.2 УК РФ.

Скептически воспринимаются высказанные отдельными криминологами суждения о целесообразности дополнения ст. 76.2 УК РФ другими вариантами посткриминального поведения, свидетельствующими о возможности исправления лица без назначения наказания с применением судебного штрафа (например, явка 
с повинной, способствование раскрытию и расследованию преступления, изобличению и уголовному преследованию других соучастников преступления) [10-12], так как в случае реализации законодателем указанных предложений возникнет столь сильное сближение положений ст. 75 УК РФ и ст. 76.2 УК РФ в части условий их применения, что эти подинституты будут фактически идентичны, и это отрицательным образом скажется на правоприменительной практике из-за возникновения конкуренции институтов освобождения от уголовной ответственности в связи с деятельным раскаянием и с назначением судебного штрафа. И вполне понятно, что не в пользу последнего.

В п. 25.1 постановления Пленума прямо указано, что решение об освобождении лица от уголовной ответственности с назначением судебного штрафа напрямую зависит от согласия виновного на применение в отношении него этих уголовно-правовых норм. Согласие потерпевшего не требуется, но учитывать его мнение необходимо.

Отметим также еще одну сформировавшуюся между нормами УК РФ рассогласованность ввиду возникновения нового подинститута, которая проявилась также и в правоприменительной практике. Штраф существовал и ранее и был отнесен к уголовным наказаниям, появление судебного штрафа, считающегося иной мерой уголовно-правового характера, который, согласно ч. 1 ст. 104.4 УК РФ, представляет собой «денежное взыскание, назначаемое судом при освобождении лица от уголовной ответственности». Содержательный анализ ч. 1 ст. 104.4 УК РФ и ч. 1 ст. 46 УК РФ показывает, что новелла УК РФ, дефинирующая судебный штраф, оказывается идентичной норме уголовного закона, раскрывающей лексическое значение штрафа как уголовного наказания. Однако в силу п. 7.1 постановления Пленума положения ст. 46 УК РФ не могут быть применимы к назначению и исполнению судебного штрафа.

Уголовное законодательство довольно строго подходит к необходимости уплаты судебного штрафа в надлежащий срок, точную дату которого устанавливает суд. Последствием несоблюдения этого нормативного положения будет отмена его назначения и привлечение виновного в совершении преступного деяния лица к уголовной ответственности в обычном порядке согласно проведенной квалификации преступления (ч. 2 ст. 104.4 УК РФ).
Согласно п. 19 постановления Пленума, лицо считается уклоняющимся от уплаты судебного штрафа, если оно не уплатило такой штраф в установленный судом срок (до истечения указанной в постановлении суда конкретной даты) без уважительных причин. Ими могут считаться такие появившиеся после вынесения постановления о прекращении уголовного дела или уголовного преследования обстоятельства, вследствие которых лицо лишено возможности выполнить соответствующие действия (например, нахождение на лечении в стационаре, утрата заработка или имущества ввиду обстоятельств, которые не зависели от этого лица). В таком случае суд должен установить новый срок уплаты штрафа.

Отмена судебного штрафа означает и отмену освобождения от уголовной ответственности, предусмотренного ст. 76.2 УК РФ. В отличие от других видов, указанный вид освобождения от уголовной ответственности носит условный характер. Здесь следует уточнить, что штраф должен быть уплачен не только в срок, но и в полном объеме. Если судебный штраф отменяется, но он при этом частично уплачен, то данное обстоятельство должно быть учтено судом при назначении наказания [13; 14].

В какой срок должен быть уплачен штраф, законом не определено, поэтому его устанавливает суд по своему усмотрению. Во всяком случае, при совершении преступления небольшой тяжести он не должен превышать более двух лет [15; 16]. По истечении этого периода истекают сроки давности привлечения лица к уголовной ответственности, и при неуплате штрафа привлечь лицо к уголовной ответственности за совершенное преступление станет невозможным. Вместе с тем сроки уплаты штрафа как уголовного наказания законодателем определены. Согласно ч. 1 ст. 31 УИК РФ, осужденный к штрафу без рассрочки выплаты обязан уплатить штраф в течение 30 дней со дня вступления приговора суда в законную силу. В целях недопущения ошибок и возможных злоупотреблений законодателю также необходимо установить и срок уплаты судебного штрафа. Руководствуясь принципами справедливости и гуманизма и учитывая сложившуюся правоприменительную практику, срок уплаты судебного штрафа следует установить в пределах от десяти дней до шести месяцев.

Помимо этого, при исполнении штрафа как уголовного наказания более суровой уголовноправовой меры, чем судебный штраф, суду с 
учетом имущественного положения осужденного и его семьи, а также с учетом возможности получения осужденным заработной платы или иного дохода предоставлена возможность рассрочить уплату штрафа на срок до пяти лет (ч. 3 ст. 46 УК РФ). У освобожденного от уголовной ответственности с назначением судебного штрафа, как отмечалось выше, также могут возникнуть проблемы с уплатой штрафа. В этом случае логичным будет предложение о предоставлении суду права предоставить как рассрочку, так и отсрочку уплаты штрафа [17, с. 3]. Срок рассрочки или отсрочки следует установить в пределах двух лет с момента совершения преступления, чтобы не истекли сроки давности привлечения к уголовной ответственности.

Если лицо не смогло полностью или частично уплатить штраф в установленные судом сроки в силу исключительных обстоятельств (например, тяжелая болезнь самого лица или его близких родственников, повлекшая инвалидность первой или второй группы, полная утрата ими имущества), то суду следует предоставить право считать это лицо освобожденным от уголовной ответственности без уплаты оставшейся части штрафа.

В случае совершения лицом нового преступления в период срока уплаты штрафа вопрос об отмене или сохранении освобождения от уголовной ответственности с назначением судебного штрафа также должен решаться судом. При отмене освобождения лицо привлекается к уголовной ответственности за совершенное преступление по соответствующей статье Уголовного кодекса, а назначение наказания осуществляется по правилам совокупности преступлений (ст. 69 УК РФ).

В ст. 104.5 УК РФ установлен порядок определения размера судебного штрафа. Согласно ч. 1 этой статьи, размер судебного штрафа определяется двумя способами: 1) он не может превышать половину максимального размера штрафа, предусмотренного соответствующей статьей Особенной части УК РФ; 2) в случае если штраф не предусмотрен соответствующей статьей, то его размер не может быть более 250 тыс. р. Таким образом, размер судебного штрафа зависит от размера штрафа как уголовного наказания.

В свою очередь, В УК РФ предусмотрено три способа установления размера штрафа как уголовного наказания: 1) в размере от 5 тыс. до 5 млн р.; 2) в размере заработной платы или иного дохода осужденного за период от двух недель до пяти лет (при этом в приговоре определяется конкретная сумма взыскиваемого штрафа); 3) в величине, кратной стоимости предмета или сумме коммерческого подкупа, взятки или сумме незаконно перемещенных денежных средств и (или) стоимости денежных инструментов (ч. 2 ст. 46). Например, в санкции ч. 1 ст. 290 УК РФ указаны все три способа. Какой из них в данном случае должен выбрать суд при назначении судебного штрафа? С учетом того что в ч. 1 ст. 104.5 УК РФ речь идет о конкретном размере судебного штрафа (250 тыс. р.), когда штраф как уголовное наказание не предусмотрен соответствующей статьей Особенной части УК РФ, размер судебного штрафа должен определяться исходя из первого способа назначения штрафа как уголовного наказания [18; 19]. Вместе с тем в санкциях статей Особенной части УК РФ штраф предусмотрен в качестве как основного, так и дополнительного вида наказания. Размер судебного штрафа следует исчислять исходя из размера штрафа, предусмотренного соответствующей статьей в качестве основного вида наказания.

В ст. 104.5 УК РФ установлен максимальный размер судебного штрафа, но в то же время не определен его минимальный размер. Применительно к штрафу как уголовному наказанию его минимальный размер определяется в самой санкции соответствующей статьи, либо, если этого нет, согласно ч. 2 ст. 46 УК РФ, он равен 5 тыс. р. Если принять во внимание, что максимальный размер судебного штрафа не может превышать половину максимального размера, предусмотренного соответствующей статьей Особенной части, логичным выглядит предложение о сокращении также наполовину и минимального размера судебного штрафа. Например, в ч. 1 ст. 202 УК РФ предусмотрен штраф в размере от 100 тыс. до 300 тыс. р. Значит, судебный штраф в этом случае может быть назначен в пределах от 50 до 150 тыс. р. Если минимальный размер штрафа не указан (например, в ст. 158.1 УК РФ штраф установлен в размере до 40 тыс. р.), то судебный штраф в данной ситуации может быть назначен в пределах от 2500 до 20 тыс. р. Для реализации указанного предложения следует внести соответствующие изменения в ст. 104.5 УК РФ.

При определении размера судебного штрафа в каждом конкретном случае суд должен учитывать тяжесть совершенного преступления, имущественное положение лица, освобождаемого от уголовной ответственности, и его семьи, а также возможность получения указанным ли- 
цом заработной платы или иного дохода (ч. 2 ст. 104.5 УК РФ) [20].

От уголовной ответственности с назначением судебного штрафа может быть освобожден и несовершеннолетний, поскольку данный вид освобождения относится к общим видам. При этом в соответствии с п. 16.2 постановления Пленума суду необходимо учитывать особенности, предусмотренные нормами гл. 14 УК РФ, касающиеся, в частности, исчисления сроков давности уголовного преследования, сроков погашения судимости, размера штрафа, который может быть назначен несовершеннолетнему в качестве наказания, и т.д. Так, согласно ч. 2 ст. 88 УК РФ, штраф как уголовное наказание назначается несовершеннолетнему в размере от 1 тыс. до 50 тыс. р. В этих же пределах несовершеннолетнему должен назначаться и судебный штраф. Вместе с тем штраф в качестве уголовного наказания назначается как при наличии у несовер- шеннолетнего осужденного самостоятельного заработка или имущества, на которое может быть обращено взыскание, так и при отсутствии таковых. Также по решению суда штраф, назначенный несовершеннолетнему осужденному, может взыскиваться с его родителей или иных законных представителей с их согласия. Думается, исходя из логики п. 16.2 постановления Пленума суду необходимо предоставить право при назначении судебного штрафа руководствоваться и этими положениями ч. 2 ст. 88 УК РФ.

Принимая во внимание правилач. 1 ст. 104.5 УК РФ, верхний предел судебного штрафа для несовершеннолетних следует уменьшить по сравнению со штрафом как уголовным наказанием наполовину, т.е. до 25 тыс. р. Особенности освобождения несовершеннолетних от уголовной ответственности с назначением судебного штрафа должны найти свое отражение в гл. 15.2 Уголовного кодекса Российской Федерации.

\section{СПИСОК ИСПОЛЬЗОВАННОЙ ЛИТЕРАТУРЫ}

1. Сабанин С. Применение судом института деятельного раскаяния / С. Сабанин, Д. Гришин // Уголовное право. 2015. - № 2. - С. 52-56.

2. Ольховик Н.В. Замена уголовного наказания в виде штрафа: миф или реальность? / Н.В. Ольховик // Уголовная юстиция. - 2015. - № 1 (5). - С. 16-19. - DOI: 10.17223/23088451/5/3.

3. Юсупов М. Вопросы применения нового вида освобождения от уголовной ответственности с назначением судебного штрафа / М. Юсупов // Уголовное право. - 2016. - № 6. - С. 122-128.

4. Екимов А.А. Назначение судебного штрафа как основание для освобождения от уголовной ответственности / А.А. Екимов // Актуальные проблемы права : материалы 5-й Междунар. науч. конф. (г. Москва, 20-23 дек. 2016 г.). - М., 2016. - С. 135-137.

5. Подройкина И.А. Спорные вопросы регламентации штрафа как уголовного наказания / И.А. Подройкина // Исторические, философские, политические и юридические науки, культурология и искусствоведение. Вопросы теории и практики. - 2015. - № 11-3 (61). - С. 119-122.

6. Минаков Г.Л. Законные интересы в уголовном праве / Г.Л. Минаков // Наука и практика. - 2008. - № 3 (36). C. 39-42.

7. Минаков Г.Л. Судебный штраф - новый вид освобождения от уголовной ответственности / Г.Л. Минаков, Л.А. Абашина // Права и свободы человека и гражданина: актуальные проблемы науки и практики : сб. науч. ст. и докл. 8-й Междунар. науч.-практ. конф. : в 2 т. / под ред. П.А. Меркулова. - Орел, 2016. - Т. 2. - С. 107-109.

8. Avdeev V.A. Harmonization criminal law means of combating crime under globalization / V.A. Avdeev, O.A. Avdeeva // The Seventh Session of the International Forum on Crime and Criminal Law in the Global Era. - Beijing, 2015. - P. 306-309.

9. Inogamova-Khegai L.V. Russian criminal science about law and judicial practice on assignment of penalty / L.V. InogamovaKhegai // The Seventh Session of the International Forum on Crime and Criminal Law in the Global Era. - Beijing, 2015. P. 350-353.

10. Кудрявцева А. Судебный штраф / А. Кудрявцева, К. Сутягин // Уголовное право. - 2016. - № 6. - С. 102-110.

11. Минская В.С. Уголовное и уголовно-исполнительное законодательство о штрафе нуждается в совершенствовании / В.С. Минская // Вестник Академии Генеральной прокуратуры Российской Федерации. - 2015. - Т. 45, № 1. - С. 79-82.

12. Шепелева С.В. К вопросу о судебном штрафе как мере уголовно-правового характера / С.В. Шепелева // Уголовная политика и правоприменительная практика : сб. ст. по материалам 4-й Всерос. науч.-практ. конф. / отв. ред. Е.Н. Рахманова. - М., 2016. - С. 378-382.

13. De La Cuesta J.L. The principle of humanity in penal law / Jose Luis De La Cuesta // International Association of Penal Law. - 2011. - Vol. 82, iss. 3. - P. 457-476. - DOI: 10.3917/ridp.823.0457.

14. Takayama Kanako. Reform of the criminal justice system in Japan / Kanako Takayama // International Association of Penal Law. - 2011. - Vol. 82, iss. 1. - P. 245-252. - DOI: 10.3917/ridp.821.0245.

15. Чемеринский К.В. Судебный штраф как иная мера уголовно-правового характера: новое направление уголовной политики / К.В. Чемеринский // Уголовная политика и культура противодействия преступности : материалы междунар. науч.-практ. конф. (30 сент. 2016 г.). - Краснодар, 2016. - С. 256-260.

16. Гриненко А.В. Судебный штраф и реалии его применения в уголовном судопроизводстве / А.В. Гриненко // Российская юстиция. - 2017. - № 1. - С. 30-31. 
17. Авдеев В.А. Условное осуждение в контексте современной уголовно-правовой политики РФ / В.А. Авдеев, О.А. Авдеева // Российская юстиция. - 2014. - № 5. - С. 2-6.

18. Иногамова-Хегай Л.В. Дифференциация и индивидуализация уголовной ответственности и иные меры уголовноправового характера / Л.В. Иногамова-Хегай // Общество и право. - 2016. - № 2 (56). - С. 98-103.

19. Иногамова-Хегай Л.В. Формализованное назначение наказания: проблемы применения / Л.В. Иногамова-Хегай // Общество и право. - 2016. - № 1 (55). - С. 46-51.

20. Taleb A. The Public Prosecutor, its role, duties and powers in the pre-trial stage of the criminal justice process - a comparative study of the French and the Shwedish legal sistems / A. Taleb, T. Ahlstrand // International Association of Penal Law. 2011. - Vol. 82, iss. 3. - P. 523-540. - DOI: 10.3917/ridp.823.0523.

\section{REFERENCES}

1. Sabanin S., Grishin D. The application of the institute of active repentance by court. Ugolovnoe pravo = Criminal Law, 2015, no. 2, pp. 52-56. (In Russian).

2. Olkhovik N.V. The substitution of fine: myth or reality? Ugolovnaya yustitsiya = Russian Journal of Criminal Law, 2015, no. 1 (5), pp. 16-19. DOI: 10.17223/23088451/5/3. (In Russian).

3. Yusupov M. Issues of application of new type of release of criminal liability with imposition of a court fine. Ugolovnoe pravo = Criminal Law, 2016, no. 6, pp. 122-128. (In Russian).

4. Ekimov A.A. Imposition of court fines as a ground for exemption from criminal liability. Aktual'nye problemy prava. Materialy 5-i Mezhdunarodnoi nauchnoi konferentsii (g. Moskva, 20-23 dekabrya 2016 g.). [Topical Issues of Law. Materials of $5^{\text {th }}$ International Scientific Conference (Moscow, December 20-23, 2016)]. Moscow, 2016, pp. 135-137. (In Russian).

5. Podroikina I.A. Controversial issues of regulating penalty as a criminal sanction. Istoricheskie, filosofskie, politicheskie $i$ yuridicheskie nauki, kul'turologiya i iskusstvovedenie. Voprosy teorii i praktiki = Historical, Philosophical, Political and Law Sciences, Culturology and Study of Art. Issues of Theory and Practice, 2015, no. 11-3 (61), pp. 119-122. (In Russian).

6. Minakov G.L. Legal interests in criminal law. Nauka i praktika = Research and Practice, 2008, no. 3 (36), pp. 39-42. (In Russian).

7. Minakov G.L., Abashina L.A. A court fine as a new type of exemption from criminal liability. In Merkulov P.A. (ed.). Prava $i$ svobody cheloveka i grazhdanina: aktual'nye problemy nauki i praktiki. Sbornik nauchnykh statei i dokladov 8-i Mezhdunarodnoi nauchno-prakticheskoi konferentsii [The Rights and Freedoms of Man and Citizen: Actual Problems of Science and Practice. Collected Research Papers and Reports of the $8^{\text {th }}$ International Research Conference]. Orel, 2016, vol. 2, pp. 107-109. (In Russian).

8. Avdeev V.A., Avdeeva O.A. Harmonization of criminal law means of combating crime under globalization. The Seventh Session of the International Forum on Crime and Criminal Law in the Global Era, Beijing, 2015, pp. 306-309.

9. Inogamova-Khegai L.V. Russian criminal science about law and judicial practice on assignment of penalty. The Seventh Session of the International Forum on Crime and Criminal Law in the Global Era. Beijing, 2015, pp. 350-353.

10. Kudryavtseva A., Sutyagin K. A Court Fine. Ugolovnoe pravo = Criminal Law, 2016, no. 6, pp. 102-110. (In Russian).

11. Minskaya V.S. Criminal and penitentiary legislation on fines needs to be improved. Vestnik Akademii General'noi prokuratury Rossiiskoi Federatsii = Bulletin of the Academy of the RF Prosecutor General's Office, 2015, vol. 45, no. 1, pp. 79-82. (In Russian).

12. Shepelyova S.V. On the question of a court fine as a measure of criminal and legal character. In Rakhmanova I.N. (ed.). Ugolovnaya politika i pravoprimenitel'naya praktika. Sbornik statei po materialam 4-i Vserossiiskoi nauchno-prakticheskoi konferentsii [Criminal Policy and the Practice of Law Enforcement. Collected Papers Based on the Materials of the $4^{\text {th }}$ All-Russian Research Conference]. Moscow, 2016, pp. 378-382. (In Russian).

13. De La Cuesta Jose Luis. The principle of humanity in penal law, International Association of Penal Law, 2011, vol. 82, iss. 3 , pp. 457-476. DOI: 10.3917/ridp.823.0457.

14. Takayama Kanako. Reform of the criminal justice system in Japan. International Association of Penal Law, 2011, vol. 82, iss. 1, pp. 245-252. DOI: 10.3917/ridp.821.0245.

15. Chemerinsky K.V. A court fine as an alternative criminal law measure: a new direction of criminal policy. Ugolovnaya politika i kul'tura protivodeistviya prestupnosti. Materialy mezhdunarodnoi nauchno-prakticheskoi konferentsii (30 sentyabrya 2016 g.) [Criminal Policy and the Culture of Counteracting Crime. Materials of the International Research Conference (September 30, 2016)]. Krasnodar, 2016, pp. 256-260. (In Russian).

16. Grinenko V.A. A judicial penalty and the realities of its application in criminal proceedings. Rossiiskaya justitsiya $=$ Russian Justice, 2017, no. 1, pp. 30-31. (In Russian).

17. Avdeev V.A., Avdeeva O.A. Probation in the context of the modern criminal law policy of the Russian Federation. Rossiiskaya justitsiya = Russian Justice, 2014, no. 5, pp. 2-6. (In Russian).

18. Inogamova-Khegai L.V. Differentiation and individualization of criminal responsibility and other measures of criminal-legal character. Obshchestvo i pravo = Society and Law, 2016, no. 2 (56), pp. 98-103. (In Russian).

19. Inogamova-Khegai L.V. Formalized assignment of penalty: problems of using. Obshchestvo $i$ pravo $=$ Society and Law, 2016, no. 1 (55), pp. 46-51. (In Russian).

20. Taleb A., Ahlstrand T. The Public Prosecutor, his role, duties and powers in the pre-trial stage of the criminal justice process - a comparative study of the French and the Swedish legal systems. International Association of Penal Law, 2011, vol. 82, iss. 3, pp. 523-540. DOI: 10.3917/ridp.823.0523.

\section{ИНФОРМАЦИЯ ОБ АВТОРАХ}

Абашина Людмила Александровна - заведующий кафедрой уголовного права Юридического института Орловского государственного университета им. И.С. Тургенева, кандидат юридических наук, доцент, г. Орел, Российская Федерация; e-mail: abashinala@yandex.ru.

\section{INFORMATION ABOUT THE AUTHORS}

Abaschina, Liudmila A. - Head, Chair of Criminal Law, Law Institute, Orel State University named after I.S. Turgenev, Ph.D. in Law, Ass. Professor, Orel, the Russian Federation; e-mail: abashinala@yandex.ru. 
Минаков Геннадий Леонидович - доцент кафедры уголовного права Юридического института Орловского государственного университета им. И.С. Тургенева, кандидат юридических наук, доцент, заслуженный юрист Российской Федерации, г. Орел, Российская Федерация; е-mail: gennadiy-minakov@mail.ru.

\section{ДЛЯ ЦИТИРОВАНИЯ}

Абашина Л.А. Судебный штраф - новая иная мера уголовно-правового характера / Л.А. Абашина, Г.Л. Минаков // Всероссийский криминологический журнал. 2018. - T. 12, № 2. - C. 266-274. - DOI: 10.17150/25004255.2018.12(2).266-274.
Minakov, Gennadiy L. - Ass. Professor, Chair of Criminal Law, Law Institute, Orel State University named after I.S. Turgenev, Ph.D. in Law, Ass. Professor, Honorary Lawyer of the Russian Federation, Orel, the Russian Federation; e-mail: gennadiy-minakov@mail.ru.

\section{FOR CITATION}

Abaschina L.A., Minakov G.L. A court fine as a new criminal law measure. Vserossiiskii kriminologicheskii zhurnal = Rus sian Journal of Criminology, 2018, vol. 12, no. 2, pp. 266-274. DOI: 10.17150/2500-4255.2018.12(2).266-274. (In Russian). 